\title{
Blasts More than 60 Percent of Bone Marrow Nucleated Cells
}

National Cancer Institute

\section{Source}

National Cancer Institute. Blasts More than 60 Percent of Bone Marrow Nucleated Cells. NCI Thesaurus. Code C154097.

A semi-quantitative microscopic finding indicating that more than 60 percent of the nucleated cells in a bone marrow sample are immature mononuclear cells. 